\title{
Performance Improvement through Skills and Work Experience at the Population and Civil Registration Office of Serang Regency
}

\author{
Khaeruman $^{1 *}$, Tabroni ${ }^{2}$ \\ ${ }^{1,2}$ Bina Bangsa University Management Study Program, Banten \\ *Corresponding author: \\ Email: khaeruman.oce@gmail.com
}

\begin{abstract}
The background of this research is that the career development of employees at the Department of Population and Civil Registration of Serang Regency tends to decline, allegedly due to a lack of skills and work experience. This study aims to determine the effect of skills and work experience partially and simultaneously on the career development of employees at the Department of Population and Civil Registration of Serang Regency.

The research method used is descriptive and quantitative. The population was 84 employees at the Department of Population and Civil Registration of Serang Regency and the sample size was 84 employees, while the sampling technique used in this study was saturated sampling. The data analysis technique used includes validity test, reliability test, classical assumptions, correlation test, coefficient of determination, multiple linear regression analysis and hypothesis testing.

The results of the study obtained a hypothesis test of the skill variable on career development which contributed $44.4 \%$ to career development (Y), while the remaining $55.6 \%$ was influenced by other variables not included in this study, work experience on career development and skills and work experience. Regarding career development, it was found that work experience $\left(X_{2}\right)$ contributed $47.7 \%$ to career development $(Y)$, while the remaining $52.3 \%$ was influenced by other variables not included in this study. Research partially there is a significant influence between skills on career development and there is a significant influence between work experience on career development. Meanwhile, simultaneously there is a significant influence between skills and work experience on career development.
\end{abstract}

Keywords: Skills, Work Experience, Career Development.

\section{INTRODUCTION}

Improving the quality of Human Resources (HR) in building a career is one of the developmental tasks that will be carried out in the life of an individual who must continue to improve his abilities in order to build a career or position he has. This is directed to optimize all abilities and strengths that exist in each individual or individual [5]. In addition, in an organization or agency every employee expects not only money to meet his daily needs, but also has the desire to be able to actualize himself. One of the important means that become a medium for self-actualization is career development, with a career development program an employee can occupy certain desired positions.

Employees in an organization have various abilities, seen from the sectors or divisions they occupy. Developments in the field of skills and work experience make organizations more sensitive in improving the quality of their resources[3]. There are also human resources or employees who occupy certain positions in the organization who have abilities that match the requirements obtained. Therefore, to address this phenomenon, it is necessary to follow up from the organization in an effort so that the abilities possessed by employees are not the same but continue to grow. One of them is the development of employee career[2]. The program is an organizational effort to maintain organizational stability in the face of challenges and global changes that occur, both public and business organizations.

Employee career development is a series of positions or positions occupied by a person during the working period both in private companies and in government circles[7]. Employee career development is one of the human resource management activities which basically has the aim of being able to improve and increase the effectiveness of the work carried out by employees so that they are increasingly able to provide 
the best contribution in realizing the organization's business goals[11]. The emergence of the phenomenon of demotion and absenteeism of employees, transfer of employees known as mutations and the existence of an employee promotion are forms of career development. The importance of agency policies is formulated to regulate the administration of all types of employee transfers.

Every employee certainly wants a development or an increase in their career. Although some employees think that one's career development is largely influenced by luck, career development still requires proper planning and utilization of good opportunities so that a career can develop as desired[7]. This is because career development is one of the official approaches that agencies can use with the intention of safeguarding the superior human resources available in the agency. Employees who want to develop a career need to pay attention to performance appraisals, and see what is superior in themselves[8].

One of the factors that influence career development is job skills. Skills can only be demonstrated through activities or training and development is done as an effort to increase the work knowledge possessed by employees. Especially facing new conditions. This is related to career and is expected to be an effort to overcome the expiration of human resources in the organization. As a form of fulfilling the needs of employees, namely the need to develop themselves which will be related to employee career development.

Another factor that influences career development is work experience. Work experience will strengthen the ability to take an action. Work experience builds an employee to be able to perform the actions known in the first step. All actions that have been done will be recorded in their subconscious and will continue throughout their life. Employees who often have work experience doing their jobs well will be very skilled and of course more professional, than those who have never taken such actions. Because the length of time working in a field will provide a skill that is getting better and better over time.

Based on observations made by researchers at the Department of Population and Civil Registration of Serang Regency, there are still problems related to employee career development, which are seen from the educational background of employees.

In addition, problems related to job skills are that there are still many employees who do not have poor skills, resulting in a lack of skilled staff in service and implementation of their duties assigned by superiors to employees. Sometimes employees who have sufficient skills feel it is unfair because there are positions based on the closeness between employees and superiors.

Employees at the Department of Population and Civil Registration of Serang Regency are still less adaptable in serving the community, due to a lack of work experience which makes it difficult for employees to serve. This is because other employees do not have the skills, work experience and responsibility for the tasks assigned to them. In fact, as an agency that has a large number of employees, the Population and Civil Registration Service must have a lot of work to be done with the professionalism of its employees. All employees are required to complete a lot of work on time.

Not only that, sometimes in the office there are misunderstandings between one employee and another and this can cause the atmosphere at work to be less conducive and uncomfortable so that employees are silent and do not reprimand each other, even greet each other in one work room and ultimately cooperate between less staff.

From this situation encourages researchers to conduct research with the title "Improving Employee Performance Through Skills and Work Experience at the Department of Population and Civil Registration, Serang Regency".

Based on the background above, the problem formulation in this study is as follows:

1. Is there any effect of skills on the career development of employees at the Department of Population and Civil Registration of Serang Regency?

2. Is there an effect of work experience on employee career development at the Department of Population and Civil Registration of Serang Regency?

3. Is there a simultaneous influence of skills and work experience on the career development of employees at the Department of Population and Civil Registration of Serang Regency?

\section{METHODS}

\section{Population and Sample}

According to Sugiyono, population is a generalization area consisting of objects or subjects that have certain qualities and characteristics that are determined by researchers to be studied and then draw conclusions[10]. Based on the above definition, the population in this study were all employees of the 
Serang Regency Population and Civil Registration Service totaling 84 employees consisting of 33 State Civil Servants (ASN) and 51 non ASN employees.

The sample is part of the number and characteristics of the population[1,10]. The sample in this study was 84 employees, while the sampling technique used in this study was saturated sampling, which is a sampling technique when all members of the population are used as the sample. This is done when the population is relatively small, 84 employees.

\section{Data Collection Methods}

Researchers observe aspects that are closely related to the problem under study more specifically so that data that supports the preparation of research reports are obtained to be processed and analyzed based on the theories that have been studied so that an overview of the object can be obtained and conclusions can be drawn about the problem under study. In this research, descriptive and quantitative methods are used.

To obtain the data needed in this study, several data research methods were used, namely:

a) Questionnaire method, is a data collection technique which is done by giving a set of written data questions to respondents with the aim of obtaining the data used in the study.

b) Interview method, this method is to obtain the required data by direct questioning with the respondent.

c) Documentation, usually done to collect secondary data from various sources both personally and institutionally.

\section{Research Instruments} reliability.

A good data collection instrument must meet two important requirements, namely validity and

\section{a) Validity}

Validity is to show the accuracy and accuracy of a measuring instrument in performing its measuring function. The level of instrument validity indicates the extent to which the collected data does not deviate from the description of the intended validity. If the validity value of each statement is greater than the $\mathrm{r}$ table value, the statement item is considered valid. In this study, validity testing was carried out using the Product Moment formula as follows:

$$
r=\frac{n\left(\sum X Y\right)-\left(\sum X\right)\left(\sum Y\right)}{\sqrt{\left(n \cdot \sum X^{2}-\left(\sum X^{2}\right)\left(n \cdot \sum Y^{2}-\left(\sum Y^{2}\right)\right.\right.}}
$$

Information:

$\mathrm{r}=$ The amount of Product Moment Correlation for each question

$\mathrm{n}=$ Number of Samples

$\mathrm{X}=$ Score Statement

$\mathrm{Y}=$ Total score of all statements from one respondent

b) Relibility

Reliability test aims to measure the instrument so that it can be trusted and produce reliable data too. Reliability shows in one sense that an instrument can be trusted enough to be used as a data collection tool because the instrument is good. Reliability testing in this study was carried out with internal consistency with the formula Cronbach's Alpha $(\alpha)$. If the Cronbach's Alpha $(\alpha)$ value is greater than 0.6 , the statement item is considered reliable or reliable. To find the Cronbach's Alpha $(\alpha)$ value using the formula:

$$
r i=\left[\frac{k}{(k-1)}\right]\left[1-\frac{\sum \sigma_{b}^{2}}{\sigma_{1}^{2}}\right]
$$

Information:

$\mathrm{r}_{\mathrm{i}} \quad=$ Instrument reliability

$\mathrm{k}=$ The number of items in the statement or question

$\sum \sigma_{b}^{2}=$ Number of grain variances 
$\sigma_{1}^{2}=$ total variance

\section{Data Analysis Techniques}

To answer the research objectives above in this study using descriptive statistics by going through the following stages:

a. Descriptive analysis

This analysis is used to analyze data by describing or describing the object of the study which consists of a description of the research, the condition of the respondents being studied and the items that are distributed from each variable. After the overall data has been collected, the next activity is processing the data then tabulating it into tables and discussing the processed data descriptively.

b. Multiple linear regression analysis

Analysis to determine the direction of the influence of the independent variable on the dependent variable, namely between skills and work experience on career development with the following regression model:

$$
\hat{\mathbf{Y}}=\mathbf{a}+\mathbf{b}_{1} \mathbf{X}_{1}+\mathbf{b}_{2} \mathbf{X}_{2}
$$

To find the values of a, b1 and b2, the equation can be used:

$$
\begin{aligned}
& \mathrm{b}_{1}=\frac{\left(\sum x_{1} y\right)\left(\sum x_{2}^{2}\right)-\left(\sum x_{2} y\right)\left(\sum x_{1} x_{2}\right)}{\left(\sum x_{1}^{2}\left(\sum x_{2}^{2}\right)\right)-\left(\sum x_{1} x_{2}\right)^{z}} \\
& \mathrm{~b}_{2}=\frac{\left(x^{2} y\right)\left(\sum w_{1}^{2}\right)-\left(\sum w_{1} x_{2}\right)\left(\sum x_{1} y\right)\left(\Sigma x_{1} x_{2}\right)}{\left(\sum w_{1}^{2}\right)\left(\Sigma w_{2}^{2}\right)-\left(\sum w_{1} x_{2}\right)^{2}} \\
& \mathrm{a}=\frac{\bar{\Sigma} y-b_{1} \Sigma x_{1}-b_{2} x_{2}}{n}
\end{aligned}
$$

Explanation:

$\hat{\mathrm{Y}}$ : Career development

a : Constant

$\mathrm{b}_{1}$ : Skills Variable Regression Coefficient $\left(\mathrm{X}_{1}\right)$

$\mathrm{b}_{2}$ : Variable Regression Coefficient Work experience $\left(\mathrm{X}_{2}\right)$

$\mathrm{X}_{1}$ : Skills

$\mathrm{X}_{2}$ : Work experience

\section{c. F test (simultaneous test)}

Simultaneous test (Test F) was used to determine the effect of the independent variables, namely skills and work experience simultaneously on employee career development at the Department of Population and Civil Registration of Serang Regency. The hypothesis model used in this F test is:

Ha: $\beta 1, \beta 2 \neq 0$; There is no effect of skills $\left(\mathrm{X}_{1}\right)$ and work experience $\left(\mathrm{X}_{2}\right)$ simultaneously on career development (Y) of employees at the Department of Population and Civil Registration of Serang Regency

Ha: $\beta 1, \beta 2 \neq 1$; There is an effect of skills $\left(\mathrm{X}_{1}\right)$ and work experience $\left(\mathrm{X}_{2}\right)$ simultaneously affecting career development $(\mathrm{Y})$ of employees at the Department of Population and Civil Registration of Serang Regency.

The value of Fcount will be compared with the value of Ftable with a confidence level of $95 \%(\alpha=5 \%)$. And the degrees of freedom with the formula: $\mathrm{df} 1=\mathrm{k}-1$ and $\mathrm{df} 2=\mathrm{n}-\mathrm{k}$, where $\mathrm{k}$ is the number of variables (free + bound) and $\mathrm{n}$ is the number of observations / samples that form the regression. The decision making criteria are:

1) If Fcount $<$ Ftable, then $\mathrm{H} 0$ is accepted and $\mathrm{Ha}$ is rejected at $\alpha=5 \%$

2) If Fcount $>$ Ftable, then $\mathrm{H} 0$ is rejected and $\mathrm{Ha}$ is accepted at $\alpha=5 \%$ 
The acceptance and rejection areas of $\mathrm{H} 0$ are shown in the following figure:

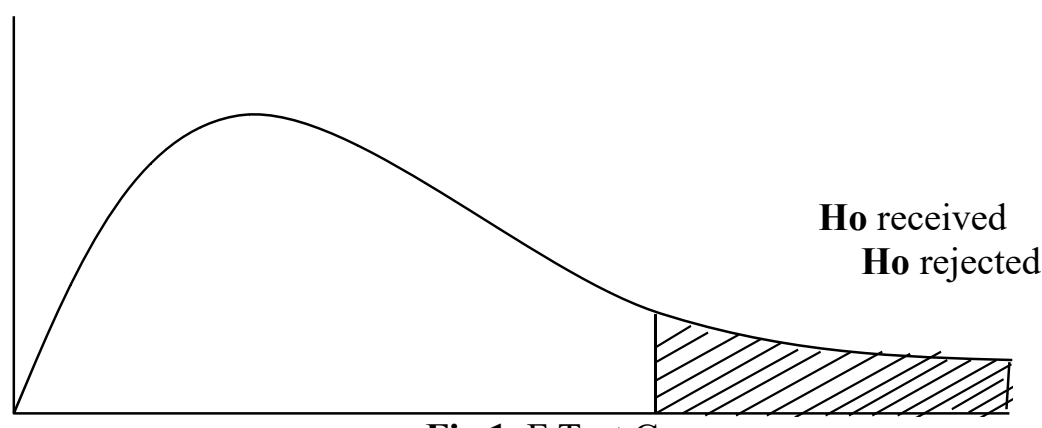

Fig 1. F Test Curr

d. $T$ test (partial test)

The t-test aims to see the effect of the independent variables, namely skills and work experience partially on employee career development at the Department of Population and Civil Registration, Serang Regency. The partial hypothesis testing criteria are as follows:

1. The influence of skill variables on career development

Ho: $\beta \mathrm{i}=0$; There is no partial effect of skills $\left(\mathrm{X}_{1}\right)$ on career development $(\mathrm{Y})$ of employees at the Department of Population and Civil Registration of Serang Regency.

Ha: $\beta \mathrm{i} \neq 0$; There is a partial effect of skills $\left(\mathrm{X}_{1}\right)$ on career development $(\mathrm{Y})$ of employees at the Department of Population and Civil Registration of Serang Regency.

2. The influence of work experience variables on career development

Ho: $\beta \mathrm{i}=0$; There is no effect of work experience $\left(\mathrm{X}_{2}\right)$ partially on the career development $(\mathrm{Y})$ of employees at the Department of Population and Civil Registration, Serang Regency.

Ha: $\beta i \neq 0$; There is an effect of work experience $\left(\mathrm{X}_{2}\right)$ partially on the career development $(\mathrm{Y})$ of employees at the Department of Population and Civil Registration of Serang Regency.

Determine the value of $t_{\text {table }}$ as the boundary of the acceptance or rejection of the hypothesis. The ttable value at $\alpha=0.05$ based on two-party test and degrees of freedom $(\mathrm{dk})=\mathrm{n}-\mathrm{k}$ where $\mathrm{n}=$ number of samples, while $\mathrm{k}=$ number of variables (free and bound).

The decision-making criteria for a partial test are:

1. If $\mathrm{t}_{\text {count }}<\mathrm{t}_{\text {table }}$, then $\mathrm{H}_{0}$ is accepted and $\mathrm{Ha}$ is rejected.

2. If $\mathrm{t}_{\text {count }}<\mathrm{t}_{\text {table }}$, then $\mathrm{H}_{0}$ is rejected and $\mathrm{Ha}$ is accepted.

The area of acceptance and rejection of $\mathrm{H} 0$ is shown in the following figure:

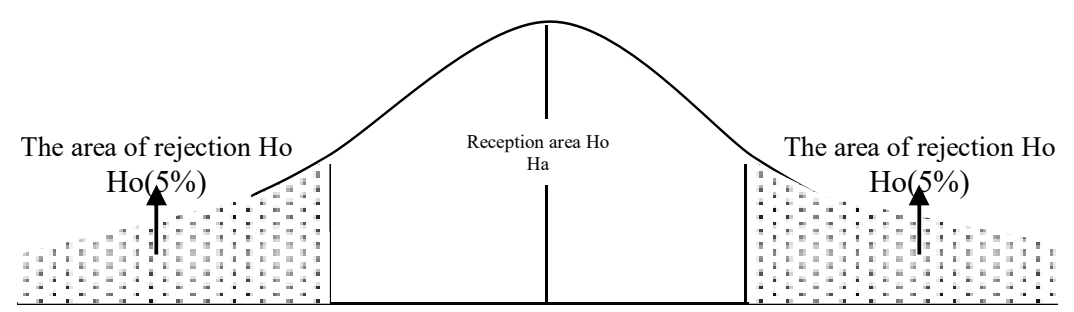

Fig 2. The t-test curve

\section{RESULT AND DISCUSSION}

\section{RESULT}

1. Testing Data Analysis Requirements

a) Skills Validity and Reliability

The results of the print out of the validity of the skill variables using SPSS are as follows: 
Table 5 Skills Validity Test $\left(\mathrm{X}_{1}\right)$

Item-Total Statistics

\begin{tabular}{|r|r|r|r|r|}
\hline & $\begin{array}{c}\text { Scale Mean if } \\
\text { Item Deleted }\end{array}$ & $\begin{array}{c}\text { Scale Variance } \\
\text { if Item Deleted }\end{array}$ & $\begin{array}{c}\text { Corrected } \\
\text { Item-Total } \\
\text { Correlation }\end{array}$ & $\begin{array}{c}\text { Cronbach's } \\
\text { Alpha if Item } \\
\text { Deleted }\end{array}$ \\
\hline P1 & 54.96 & 29.866 & .390 & .789 \\
P2 & 54.94 & 29.816 & .412 & .786 \\
P3 & 55.30 & 31.175 & .342 & .791 \\
P4 & 54.86 & 30.750 & .358 & .790 \\
P5 & 55.21 & 30.435 & .394 & .787 \\
P6 & 54.94 & 29.599 & .466 & .782 \\
P7 & 54.86 & 31.136 & .374 & .789 \\
P8 & 54.83 & 31.321 & .407 & .787 \\
P9 & 55.35 & 30.687 & .387 & .788 \\
P10 & 55.08 & 30.848 & .389 & .788 \\
P11 & 55.01 & 29.747 & .441 & .784 \\
P12 & 55.20 & 30.308 & .423 & .785 \\
P13 & 54.96 & 29.818 & .486 & .780 \\
P14 & 54.86 & 31.136 & .374 & .789 \\
P15 & 54.80 & 31.175 & .485 & .783 \\
\hline
\end{tabular}

Source: Results of SPSS v.21 Processing

Based on Table 5, it consists of 15 statement items. The $r_{\text {count }}$ value from statement 1 to statement 15 can be seen in the column corrected item-total correlation. Furthermore, the $r_{\text {count }}$ value is compared with the $r$ table using the number of respondents as much as 84, the $r$ table value is obtained with an error rate of $5 \%$ or 0.05 and $n=84$, then $r$ table $=0.212$ (table of $r$ Product Moment values). The comparison of $r_{\text {count }}$ and $r_{\text {table }}$ can be seen in the following table:

Table 6 Results of Skills Validity Testing

\begin{tabular}{|c|c|c|c|}
\hline Statement & $\mathrm{r}_{\text {count }}$ & $\mathrm{r}_{\text {table }}$ & Information \\
\hline P1 & 0,390 & 0,212 & Valid \\
\hline P2 & 0,412 & 0,212 & Valid \\
\hline P3 & 0,342 & 0,212 & Valid \\
\hline P4 & 0,358 & 0,212 & Valid \\
\hline P5 & 0,394 & 0,212 & Valid \\
\hline P6 & 0,466 & 0,212 & Valid \\
\hline P7 & 0,374 & 0,212 & Valid \\
\hline P8 & 0,407 & 0,212 & Valid \\
\hline P9 & 0,387 & 0,212 & Valid \\
\hline P10 & 0,389 & 0,212 & Valid \\
\hline P11 & 0,441 & 0,212 & Valid \\
\hline P12 & 0,423 & 0,212 & Valid \\
\hline P13 & 0,486 & 0,212 & Valid \\
\hline P14 & 0,374 & 0,212 & Valid \\
\hline P15 & 0,485 & 0,212 & Valid \\
\hline
\end{tabular}

Source: Processed data

Based on the results of data processing, it is known that the $r_{\text {count }}$ value of all items in the skill variable $\left(X_{1}\right)$ results in a total of each statement item greater than $0.212\left(r_{\text {count }}>r_{\text {tabel }}\right)$. This shows that all 
statement items in the skill variable are said to be valid. The results of the reliability printout of the skill variables are as follows:

Table 7 Reliability Test of Skills Variables

Reliability Statistics

\begin{tabular}{|r|r|}
\hline $\begin{array}{c}\text { Cronbach's } \\
\text { Alpha }\end{array}$ & N of Items \\
\hline .798 & 15 \\
\hline
\end{tabular}

Source: Results of SPSS v.21 Processing

Based on Table 7, the calculation of the Cronbach Alpha $=0.798$ reliability coefficient is greater than 0.6 , it can be concluded that the skill variable is said to be reliable so that it can be used as further testing material.

b) Validity and Reliability of Work Experience

The results of the work experience validity print out using SPSS are as follows:

Table 8 Testing the Validity of Work Experience $\left(\mathrm{X}_{2}\right)$

Item-Total Statistics

\begin{tabular}{|r|r|r|r|r|}
\hline & $\begin{array}{c}\text { Scale Mean if } \\
\text { Item Deleted }\end{array}$ & $\begin{array}{c}\text { Scale Variance if } \\
\text { Item Deleted }\end{array}$ & $\begin{array}{c}\text { Corrected Item- } \\
\text { Total Correlation }\end{array}$ & $\begin{array}{c}\text { Cronbach's } \\
\text { Alpha if Item } \\
\text { Deleted }\end{array}$ \\
\hline P1 & 53.79 & 37.110 & .415 & .822 \\
P2 & 54.05 & 35.805 & .361 & .826 \\
P3 & 53.96 & 36.975 & .288 & .830 \\
P4 & 54.07 & 36.356 & .357 & .826 \\
P5 & 54.25 & 34.599 & .597 & .811 \\
P6 & 53.98 & 34.578 & .547 & .813 \\
P7 & 54.37 & 35.031 & .528 & .815 \\
P8 & 54.10 & 36.087 & .411 & .822 \\
P9 & 53.99 & 36.301 & .320 & .829 \\
P10 & 54.29 & 34.809 & .537 & .814 \\
P11 & 53.81 & 35.626 & .396 & .824 \\
P12 & 53.81 & 36.783 & .423 & .822 \\
P13 & 54.23 & 34.876 & .585 & .812 \\
P14 & 53.98 & 34.698 & .510 & .816 \\
P15 & 54.35 & 34.735 & .538 & .814 \\
\hline
\end{tabular}

Source: Results of SPSS v.21 Processing

Based on Table 8, it consists of 15 statement items. The $r_{\text {count }}$ value from statement 1 to statement 15 can be seen in the corrected item-total correlation column. Furthermore, the $r_{\text {count }}$ value is compared with the $\mathrm{r}$ table using the number of respondents as much as 84 , the $r$ table value is obtained with an error rate of $5 \%$ or 0.05 and $n=84$, then $r$ table $=0.212$ (table of $r$ Product Moment values). The comparison of $r_{\text {count }}$ and $\mathrm{r}_{\text {table }}$ can be seen in the following table:

Table 9 Results of Work Experience Validity Testing

\begin{tabular}{|c|c|c|c|}
\hline Statement & $\mathrm{r}_{\text {count }}$ & $\mathrm{r}_{\text {table }}$ & Information \\
\hline P1 & 0,415 & 0,212 & Valid \\
\hline P2 & 0,361 & 0,212 & Valid \\
\hline P3 & 0,288 & 0,212 & Valid \\
\hline P4 & 0,357 & 0,212 & Valid \\
\hline P5 & 0,597 & 0,212 & Valid \\
\hline P6 & 0,547 & 0,212 & Valid \\
\hline
\end{tabular}




\begin{tabular}{|c|c|c|c|}
\hline P7 & 0,528 & 0,212 & Valid \\
\hline P8 & 0,411 & 0,212 & Valid \\
\hline P9 & 0,320 & 0,212 & Valid \\
\hline P10 & 0,537 & 0,212 & Valid \\
\hline P11 & 0,396 & 0,212 & Valid \\
\hline P12 & 0,423 & 0,212 & Valid \\
\hline P13 & 0,585 & 0,212 & Valid \\
\hline P14 & 0,510 & 0,212 & Valid \\
\hline P15 & 0,538 & 0,212 & Valid \\
\hline
\end{tabular}

Source: Processed data

Based on the results of data processing, it is known that the rcount value of all items in the work experience variable $\left(\mathrm{X}_{2}\right)$ results in a total of each statement item greater than $0.212\left(\mathrm{r}_{\text {count }}>\mathrm{r}_{\text {tabel }}\right)$. This shows that all statement items in the work experience variable are said to be valid. The results of the work experience variable reliability print out are as follows:

Table 10 Variable Reliability Test Work experience

\begin{tabular}{|l|r|}
\multicolumn{2}{c|}{ Reliability Statistics } \\
\hline $\begin{array}{c}\text { Cronbach's } \\
\text { Alpha }\end{array}$ & N of Items \\
\hline .830 & 15 \\
\hline
\end{tabular}

Source: SPSS Processing Results

Based on Table 10, the calculation results of the Cronbach Alpha reliability coefficient $=0.830$ are greater than 0.6 , so it can be concluded that the work experience variable is said to be reliable so that it can be used as further testing material.

c) Validity and Reliability of Career Development

The print out results of the validity of career development using SPSS are as follows:

Table 11 Testing the Validity of Career Development (Y)

Item-Total Statistics

\begin{tabular}{|r|r|r|r|r|}
\hline & $\begin{array}{c}\text { Scale Mean if } \\
\text { Item Deleted }\end{array}$ & $\begin{array}{r}\text { Scale Variance } \\
\text { if Item Deleted }\end{array}$ & $\begin{array}{c}\text { Corrected Item- } \\
\text { Total Correlation }\end{array}$ & $\begin{array}{c}\text { Cronbach's Alpha } \\
\text { if Item Deleted }\end{array}$ \\
\hline P1 & 54.33 & 41.984 & .355 & .856 \\
P2 & 54.17 & 42.574 & .451 & .851 \\
P3 & 54.11 & 41.663 & .492 & .848 \\
P4 & 54.01 & 42.663 & .428 & .851 \\
P5 & 54.45 & 40.612 & .570 & .844 \\
P6 & 54.24 & 39.702 & .546 & .845 \\
P7 & 54.17 & 41.177 & .472 & .849 \\
P8 & 54.35 & 41.169 & .485 & .849 \\
P9 & 54.40 & 40.605 & .493 & .848 \\
P10 & 54.62 & 40.431 & .552 & .845 \\
P11 & 54.08 & 40.487 & .600 & .843 \\
P12 & 54.24 & 39.075 & .565 & .844 \\
P13 & 54.30 & 41.079 & .416 & .853 \\
P14 & 54.58 & 40.800 & .515 & .847 \\
P15 & 54.12 & 40.347 & .492 & .848 \\
\hline
\end{tabular}

Source: SPSS Processing Results 
Based on Table 11, it consists of 15 statement items. The rcount value from statement 1 to statement 15 can be seen in the corrected item-total correlation column. Furthermore, the $r_{\text {count }}$ value is compared with rtable. By using the number of respondents as much as 84, the value of $r_{\text {table }}$ is obtained with an error rate of $5 \%$ or 0.05 and $n=84$, then $r_{\text {table }}=0.212$ (table of $r$ Product Moment values). The comparison of rcount and rtable can be seen in the following table:

Table 12 Results of Career Development Validity Testing

\begin{tabular}{|c|c|c|c|}
\hline Statement & $\mathrm{r}_{\text {count }}$ & $\mathrm{r}_{\text {table }}$ & Information \\
\hline P1 & 0,355 & 0,212 & Valid \\
\hline P2 & 0,451 & 0,212 & Valid \\
\hline P3 & 0,492 & 0,212 & Valid \\
\hline P4 & 0,428 & 0,212 & Valid \\
\hline P5 & 0,570 & 0,212 & Valid \\
\hline P6 & 0,546 & 0,212 & Valid \\
\hline P7 & 0,472 & 0,212 & Valid \\
\hline P8 & 0,485 & 0,212 & Valid \\
\hline P9 & 0,493 & 0,212 & Valid \\
\hline P10 & 0,552 & 0,212 & Valid \\
\hline P11 & 0,600 & 0,212 & Valid \\
\hline P12 & 0,565 & 0,212 & Valid \\
\hline P13 & 0,416 & 0,212 & Valid \\
\hline P14 & 0,515 & 0,212 & Valid \\
\hline P15 & 0,492 & 0,212 & Valid \\
\hline
\end{tabular}

Source: Results of SPSS v.21 Processing

Based on the results of data processing, it is known that the rcount value of all items in the career development variable $(\mathrm{Y})$ results in a total of each statement item greater than $0.212\left(\mathrm{r}_{\text {count }}>\mathrm{r}_{\text {tabel }}\right)$. This shows that all statement items in the career development variable are said to be valid. The results of the reliability print out of the career development variable are as follows:

Table 13 Variable Reliability Test Career development

\section{Reliability Statistics}

\begin{tabular}{|r|r|}
\hline $\begin{array}{c}\text { Cronbach's } \\
\text { Alpha }\end{array}$ & N of Items \\
\hline .857 & 15 \\
\hline
\end{tabular}

Source: SPSS Processing Results

Based on Table 13, the calculation of the Cronbach Alpha $=0.857$ reliability coefficient is greater than 0.6 , it can be concluded that the career development variable is said to be reliable or reliable so that it can be used as further testing material

\section{DISCUSSION}

\section{Skills on Career Development}

The first hypothesis that is put forward states that it is suspected that there is a significant effect of skills on the career development of employees at the Department of Population and Civil Registration of Serang Regency. Based on the results of the SPSS calculation, the $t_{\text {count }}$ value is 3,913 and the $t_{\text {table }}$ value is 1.989 with a significance value of 0,000 because the t-count value is greater than t-table and the significance value is less than 0.05 , so the first hypothesis is accepted, which means that there is a significant influence between skills on the career development of employees at the Department. Serang Regency Population and Civil Registration.

Based on the results of the SPSS calculation, the coefficient of determination seen from the R Square is 0.444 . It can be concluded that skills $\left(\mathrm{X}_{1}\right)$ contributed $44.4 \%$ to career development $(\mathrm{Y})$, while the remaining $55.6 \%$ was influenced by other variables not included in this study. 
The results of this study are in accordance with research conducted by Arisandy (2015) and Arisandy (2017) which concluded that skills have a significant effect on career development[2].

\section{The Effect of Work Experience on Career Development}

The second hypothesis that is put forward states that it is suspected that there is a significant effect of work experience on the career development of employees at the Department of Population and Civil Registration of Serang Regency. Based on the results of the SPSS calculation, the $t_{\text {count }}$ value of 4.627 and $t$ table of 1.989 with a significance value of 0.000 because the $t_{\text {count }}$ is greater than $t_{\text {table }}$ and the significance value is less than 0.05 , so the second hypothesis is accepted, which means that there is a significant influence between work experience on employee career development at Department of Population and Civil Registration of Serang Regency.

Based on the results of the SPSS calculation, the coefficient of determination seen from the R Square is 0.477 . It can be concluded that work experience $\left(\mathrm{X}_{2}\right)$ contributed $47.7 \%$ to career development $(\mathrm{Y})$, while the remaining $52.3 \%$ was influenced by other variables not included in this study.

The results of this study are in accordance with research conducted by Setyadi (2015) and Sudana (2015) and Haryani (2015), which conclude that work experience has a significant influence on career development.

\section{Skills and Work Experience on Career Development}

The third hypothesis states that it is suspected that there is a significant influence on skills and work experience simultaneously on the career development of employees at the Department of Population and Civil Registration of Serang Regency. Based on the results of the calculation of SPSS F count $_{\text {of }} 51.616$ and $F_{\text {table }}$ of 3.11 with a significance value of 0.000 . Based on the significance test, the $F_{\text {count }}$ value is greater than $\mathrm{F}_{\text {table }}$ and the significance value is 0.000 , so it is significant because it is less than 0.05 , so the third hypothesis is accepted, which means that there is a significant influence between skills and work experience simultaneously on the career development of employees at the Population and Civil Registration Service. Serang Regency.

The correlation value between skills and work experience on career development is 0.749 , thus it can be concluded that the variable skills (X1) and work experience $\left(\mathrm{X}_{2}\right)$ on the career development variable (Y) have a strong level of influence. Based on the Interpretation Table of the Correlation Coefficient from Sugiyono the value of 0.749 is in the range of $0.600-0.799$ (strong).

Based on the results of the SPSS calculation, the coefficient of determination seen from the $\mathrm{R}$ Square is 0.560 . It can be concluded that skills (X1) and work experience $\left(\mathrm{X}_{2}\right)$ contributed $56 \%$ to career development $(\mathrm{Y})$, while the remaining $44 \%$ was influenced by other variables not included in this study.

The results of this study are in accordance with the research conducted by Arisandy (2015) which concludes that skills and work experience have a significant influence on career development.

\section{CONCLUSION}

Based on the research data that has been obtained, the researcher can draw conclusions, including:

1. Based on the significance test, it is found that there is a significant influence between skills on the career development of employees at the Department of Population and Civil Registration of Serang Regency. The coefficient of determination seen from R Square is 0.444 . It can be concluded that skills $\left(\mathrm{X}_{1}\right)$ contributed $44.4 \%$ to career development $(\mathrm{Y})$, while the remaining $55.6 \%$ was influenced by other variables not included in this study.

2. Based on the significance test, it is found that there is a significant influence between work experience and career development of employees at the Department of Population and Civil Registration of Serang Regency. The coefficient of determination seen from the R Square is 0.477 . It can be concluded that work experience $\left(\mathrm{X}_{2}\right)$ contributed $47.7 \%$ to career development $(\mathrm{Y})$, while the remaining $52.3 \%$ was influenced by other variables not included in this study.

3. Based on the significance test, it is found that simultaneously there is a significant influence between skills and work experience together on the career development of employees at the Department of Population and Civil Registration of Serang Regency. The coefficient of determination seen from $R$ 
Square is 0.560 . It can be concluded that skills $\left(\mathrm{X}_{1}\right)$ and work experience $\left(\mathrm{X}_{2}\right)$ contribute $56 \%$ to career development (Y), while the remaining $44 \%$ is influenced by other variables not included in this study.

\section{ACKNOWLEDGMENTS}

The author thanks, to the leadership of the Serang Regency Population and Civil Registration Service, to all parties, who have helped in completing this research, and thank you for completing this research, and thank you to a friend of the Bina Bangsa Banten University lecturer who has helped for the research results. that we're working on.

\section{REFERENCES}

[1] Arikunto, Suharsimi. 2012. Practical Research Procedures. Jakarta: Rineka Cipta.

[2] Arisandy, Moh. Rum. 2015. The Influence of Skills and Work Experience on Employee Career Development at the Donggala District Education Office, Catalogist e-Journal. Volume 3. Number 8.

[3] Hasibuan, Malayu S.P. 2013. Human Resource Management. Jakarta: PT. Earth Literacy.

[4] Mangkunegara, Anwar Prabu. 2013. Company Human Resource Management. Bandung: PT. Youth Rosdakarya.

[5] Manullang. 2009. Management Basics. Yogyakarta: GMU Press.

[6] Notoatmodjo, Soekidjo. 2009. Human Resource Development. Jakarta: PT.Rineka Cipta.

[7] Rivai, Veithzal. 2011. Human Resource Management for Companies. Jakarta: PT. Raja Grafindo Persada.

[8] Robbins, Stephen P. 2012. Organizational Behavior. Jakarta: Erlangga.

[9] Sedarmayanti. 2011. Human Resources and Work Productivity. Bandung: Mandar Maju.

[10] Sugiyono. 2012. Business Research Methods. Bandung: Alfabeta.

[11] Sutrisno, Edi. 2017. Human Resource Management. Jakarta: Kencana Prenada Media Group. 